Karolina J. Dudek

ORCID: https://orcid.org/0000-0002-1200-7213

Akademia Leona Koźmińskiego

\title{
U siebie w biurze. Materialne środowisko homo officens
}

\author{
At home in the office. Homo officens material environment
}

\begin{abstract}
The article discusses the processes of domesticating offices and making the workplace feel like home. First, the author describes the ways of taming and personalizing territorial offices: she analyses the ways of bottom-up shaping and taming of the workplace, inscribing one's identity and biography, as well as resistance and contestation - tactics that constitute answers to corporate strategies. Next, she discusses changes in the arrangement of work space in non-territorial offices. The author concludes that manufacturers of office furniture are important actors who shape the processes of the domestication of space in offices, capturing both tactics and strategies.
\end{abstract}

Keywords: offices, workplace, work, office furniture

$\mathrm{W}$ artykule przedstawiono procesy zadomawiania się w przestrzeni biurowej. Autorka opisuje najpierw sposoby oswajania i personalizowania biur terytorialnych: analizuje sposoby oddolnego kształtowania i oswajania przestrzeni pracy, wpisywania w nią tożsamości i biografii pracowników, a także oporu i kontestacji, czyli taktyk, które są odpowiedzią na strategie korporacyjne. Następnie omawia zmiany w aranżacji przestrzeni pracy w biurach nieterytorialnych. Autorka pokazuje też, jak ważną rolę w tych procesach odgrywają producenci mebli biurowych, kształtujący i przechwytujący zarówno taktyki, jak i strategie związane $\mathrm{z}$ organizacją przestrzeni biurowej.

Słowa kluczowe: biura, środowisko pracy, praca, meble biurowe

Odebrano / Received: 31.01.2019

Zaakceptowano / Accepted: 27.08.2019 


\section{Wprowadzenie}

Czym jest miejsce? Czym różni się ono od przestrzeni? To ważne pytania antropologiczne, na które odpowiedzi poszukiwali najważniejsi teoretycy. Przestrzeń jest bardziej abstrakcyjna niż miejsce. W pewnym sensie jest niedookreślona. To, co najpierw jest przestrzenią, staje się powoli miejscem, w miarę jak jest poznawane, oswajane dzięki uzyskiwaniu określeń i znaczeń ${ }^{1}$. Gdyby jednak odnieść te pytania do współczesnych, korporacyjnych biur, jakie odpowiedzi można by otrzymać? Czym może być „miejsce pracy”? Czym różni się ono od „przestrzeni pracy”? Jak „przestrzeń pracy” staje się „moim miejscem pracy”?

Ten, kto szukać będzie fotografii biur w bankach obrazów, znajdzie fotografie przestrzeni uporządkowanych, „odświętnie” przygotowanych na sesję fotograficzną: meble o czystych blatach wypełniają przestrzeń, która bez nich byłaby zupełnie pusta ${ }^{2}$. Rzeczywistość oglądana okiem badacza i jego rozmówców ma niewiele wspólnego z tym, co przedstawiają typowe obrazy z banków, i jest chaotycznie wypełniona przedmiotami, często zabałaganiona i oswajana na różne sposoby. Potrzeba udomowienia, humanizowania, ale też symbolicznego brania w posiadanie - oznaczania terytorium ujawnia się z całą mocą w nowoczesnych przestrzeniach korporacyjnych.

Dlatego w niniejszym artykule postanowiłam przybliżyć sposoby zadomawiania się w przestrzeni pracy. Odpowiadam na pytania:

1. W jaki sposób biura są oswajane?

2. Jak ludzie wpisują w korporacyjne przestrzenie siebie i swoją tożsamość? Kiedy oswajanie staje się taktyką w rozumieniu Michela de Certeau ${ }^{3}$, sposobem na manifestowanie oporu czy też metodą kontestacji polityk i norm korporacyjnych?

3. Jakie nowe strategie organizacyjne związane $\mathrm{z}$ zarządzaniem przestrzenią można wyróżnić i jak wpływają one na taktyki zadomawiania?

Pokazuję też, że producenci mebli biurowych umiejętnie przechwytują praktyki oswajania przestrzeni i wykorzystują je, by tworzyć własne strategie.

\section{Biura terytorialne. Oswajanie przestrzeni}

W tradycyjną koncepcję biura wpisana jest terytorialność: każdy dział i pracownik znajduje się w przypisanej mu przestrzeni. Część podziałów terytorium ma charakter formalny i jest odgórnie narzucona, a część wynika z nieformalnych praktyk. Każda

1 Tuan 1987, s. 173.

2 Artykuł napisany w ramach grantu „Tworzenie i przechwytywanie wartości w polskich przedsiębiorstwach z branży meblarskiej. Badanie ilościowo-jakościowe”, 2014/15/D/HS4/01173, Narodowe Centrum Nauki Sonata 8, kierownik projektu: dr Paulina Bednarz-Łuczewska.

3 de Certeau 2008. 
przestrzeń biura jest bowiem niehomogeniczna, składa się z wielu niewidzialnych, wzajemnie przenikających się stref.

Zajmowanie przydzielonej przestrzeni wiąże się z działaniem. W ten sposób każdy z użytkowników ma jakiś, choćby niewielki wkład w tworzenie biura: coś do niego przyniesie, coś przestawi. W toku użytkowania biura przestrzeń stopniowo jest wypełniana różnymi przedmiotami. $Z$ perspektywy architekta proces tworzenia biura kończy się wraz $\mathrm{z}$ oddaniem powierzchni potwierdzonym odpowiednimi protokołami. $Z$ perspektywy antropologa czy osób w nich pracujących trwa on o wiele dłużej i właściwie nigdy nie można uznać go za skończony.

Zakres swobody w przekształcaniu poszczególnych stref regulowany jest przez strategie. W każdym biurze jest część reprezentacyjna, choć niekiedy ograniczona do recepcji i sal konferencyjnych, silnie skodyfikowana, opatrzona znacznikami organizacji, przynależna do przestrzeni formalnej, w której przyjmowani są goście. Są też przestrzenie nieformalne, będące strefą, do której dostęp mają przede wszystkim osoby pracujące w danej organizacji. O ile w tej pierwszej, formalnej, prowadzona jest w większym stopniu kontrola aranżacji, o tyle w przestrzeniach nieformalnych dopuszcza się więcej ingerencji oddolnych - to pole taktyk.

W tych ostatnich strefach przynoszonych i pozostawianych jest wiele rzeczy, nie tylko to, co jest niezbędne do wykonywania pracy, lecz także zdjęcia rodzinne, maskotki, ulubione naczynia (kubki i talerzyki), pamiątki wakacyjne. Na ścianach wieszane są obrazy o różnej tematyce, a wśród nich: plakaty filmowe, plakaty ze zwierzętami, roznegliżowanymi kobietami i mężczyznami, wydrukowane memy, obrazki z komiksów. Pojawiają się też symbole i wizerunki religijne - krzyże i portrety Jana Pawła II. Pracownicy w szafach chowają odzież i obuwie (torby z rzeczami na trening, stroje do jazdy na motocyklu, rzeczy na zmianę i zapasowe buty, których kobiety przechowują nieraz po kilka par). Jeśli szafy są już zajęte, rzeczy te umieszczane są zazwyczaj w mniej widocznym miejscu (w kącie przy biurku lub gdzieś pod oknem).

$\mathrm{Z}$ nagromadzenia rzeczy można nawet nie zdawać sobie sprawy, dopóki nie przyjrzy się konkretnej przestrzeni. Dobrze oddaje to jednak poniższy cytat z opowieści menedżerki HR z warszawskiej korporacji:

Każdy ma swoją szafkę, nie tylko pod biurkiem na dokumenty, ale taką szafkę stojącą, taką metr dwadzieścia, na różne rzeczy. One są generalnie na dokumenty, tylko że my nie generujemy żadnych dokumentów, więc to jest taka szafka na to, żeby tam buty trzymać, torebkę, żeby się nie niszczyła. Tam mamy Kodeks pracy. Dziewczyny czasem przyczepiają tam zdjęcia - taki locker jak w liceum. Próbują mi to zabrać od półtora roku, ale ja im mówię, że to jest bardzo ważne dla mojego biznesu. Więc mamy dziesięć pustych szafek. Dziewczyny tam trzymają, na przykład, pieczywo ryżowe. Nad tymi szafami mamy biały whiteboard taką dużą tablicę, na której zapisujemy sobie różne rzeczy, ale też, na przykład, przyklejamy tam rysunki naszych dzieci, albo ktoś coś wymyślił głupiego, to sobie też tam przyczepiamy. 
A obok tego mamy wielki kalendarz, ponieważ głównie pracujemy dla Francuzów, więc mamy ogromny francuski kalendarz pracy. Jak wiemy, Francuzi się nie przemęczają, lubią mieć święta, więc trzeba być na bieżąco, kiedy jest jakie święto francuskie. Mamy tam też zakątek kawowo-herbaciany. Firma oczywiście na początku nie miała tego benefitu. Dopiero od niedawna kawa i herbata jest na wyposażeniu w kuchni. Natomiast my mamy swoje. Bo u nas jest ZUS, nie? Musi być kawa, ciasteczko, więc jest taki zakątek, w którym rzeczywiście mamy chyba $z$ dwadzieścia smaków herbaty, kawy - na co kto ma ochotę. Jak ktoś gdzieś jedzie, to zawsze przywozi herbatę z danego kraju. Bardzo fancy. Dalej mamy The Hall of Fame, czyli ścianę, na której się przyczepia dyplomy z zakończonych szkoleń. Jak ktoś zakończył szkolenie, to nie zabiera dyplomu do domu, tylko przykleja go na ścianę. Obok mamy tablicę korkową, na której mamy wszystkie głupoty: zdjęcia z tych wszystkich krajów, w których byliśmy, i kto był na jakim koncercie. Jak ktoś chce coś przyczepić, to przyczepia do tej tablicy, więc to jest taka naprawdę już makietka rodzinna. Przy tej tablicy stoją wszystkie item'y, które dostawaliśmy od naszych gości. Więc mamy tam taki malutki samochodzik „resorakowy” z Filipin i jajko niespodziankę, i piórnik z pokemonami. Na ostatniej ścianie mamy coś, co powstało podczas wizyty bardzo, bardzo ważnego klienta: mamy zdjęcia wszystkich pracowników wydrukowane w bardzo dużym formacie, tak że widać je nawet $\mathrm{z}$ końca open space’u. I pod tymi zdjęciami jest informacja, kto obsługuje jaki region. Mamy nawet taki urban mit, taką legendę, ale to się sprawdza niestety, że jak ktoś odpada od tej ściany, jak się odkleja czyjeś zdjęcie, to znaczy, że ta osoba się zwalnia. Jak ktoś przychodzi nowy, to ma ściągę na ścianie: Ola pracuje, na przykład, z North America, a ktoś tam pracuje z Hiszpanią. Bardzo fajnym projektem, który chcemy ukraść od działu finansowego, jest tablica ze zdjęciami dzieci pracowników, które się urodziły, kiedy oni tam pracowali. Rodzę dziecko i przynoszę zdjęcia tego dziecka do pracy. I w tym dziale finansowym jest wielka tablica z napisem „finansiątka” - i po prostu zdjęcia „finansiątek” wiszą, i to jest takie słodkie, supersłodkie. I my też chcemy to robić. To są takie właśnie „oswajacze", miłe rzeczy. Mamy jeszcze osobne szafki na buty. Był wielki problem zimowy, żeby buty nie były w tej samej szafie, w której są kurtki, bo to jednak śmierdzi. Fajniej byłoby mieć szafkę osobistą. Bo jednak te szafy wbudowane albo stoją puste, bo wszyscy trzymają wszystkie rzeczy u siebie albo trzymają w nich parasole, jakieś dziwne rzeczy, typu strój na siłownię. Lepiej byłoby zrobić takie szafki indywidualne, na kluczyk, w których można byłoby takie swoje rzeczy przechowywać. Na dużo więcej pozwalamy pracownikom pracującym na telefonie. Organizacja rozumie, że to jest bardzo trudna praca, bardzo frustrująca, i dlatego oni mogą sobie pozwolić na dużo więcej. Na przykład na porozwieszanie zdjęć ze Stevenem Seagalem albo z Brucem Lee, na przerabianie zdjęć z głową szefa i rozwieszenie ich wszędzie. Albo z napisami: Keep calm and eat cup cakes. Zdajemy sobie sprawę z tego, że oni muszą odreagować. To są bardzo trudne rozmowy i bardzo ciężka praca.

${ }^{4} \mathrm{~W}$ opowieściach rozmówców jest bardzo dużo anglicyzmów. Spolszczone wersje angielskich pojęć są także wykorzystywane powszechnie na oznaczenie typów przestrzeni i mebli w biurach czy sposobu 
W opisywanym biurze nagromadzenie przedmiotów powstaje wskutek skoordynowanych, zinstytucjonalizowanych praktyk, ale też spontanicznej działalności. W opowieści menedżerki uderza wielość przedmiotów, które nie są narzędziami niezbędnymi do wykonywania codziennych zadań, oraz niedostosowanie systemów przechowywania do rzeczywistych potrzeb. Ikonosfera - nazwę tak całą tę symboliczną sferę „przedmiotów-oswajaczy" - w każdej organizacji wygląda nieco inaczej, ale pewne typy przedmiotów, takie jak pamiątki, prezenty, dyplomy, obrazki, można znaleźć w większości biur. W tym sensie jest ono dość typowe. Przestrzeń staje się narzędziem tworzenia poczucia wspólnoty, materializowania tożsamości zarówno indywidualnych, jak i zbiorowych.

Wiele niepozornych przedmiotów jest bogatych w znaczenia. Pozwalają snuć opowieści o poszczególnych osobach, ale też o relacjach w zespole i praktykowanych wartościach. Przykład z innego biura: plastikowy diadem, który zauważyłam na biurku Marka, menedżera projektu w pewnej korporacji. Pomyślałam w pierwszym momencie, że najwidoczniej dzieci musiały go odwiedzić w biurze. Zapytałam jednak, czy to zabawka zostawiona przez córkę. „Nie to moja. Nasza” - odpowiedział. Osoby zgromadzone w pokoju wybuchnęły niepohamowanym śmiechem. Diadem nosił ten, kto nadmiernie "gwiazdorzył” albo miał „fochy księżniczki”. „I tak się składa, że to jest najczęściej Marek" - twierdziły jego koleżanki. Diadem materializował to, co było ważne dla zespołu, i symbolicznie to wyrażał. Poczucie humoru, serdeczność i koleżeńskość, docenianie dobrej atmosfery w pracy - opowieść o diademie kondensowała wszystkie te wartości. To zadomawianie przez przedmioty, które są zmaterializowanymi opowieściami. Jednocześnie diadem był narzędziem społecznej kontroli niepożądanych zachowań i emocji. Tak samo jest $z$ przestrzenią biura, która $z$ jednej strony zapewnia pracownikom płaszczyznę działania i realizowania się, z drugiej jest czynnikiem ograniczającym swobodę działania. Przestrzeń biura jest też urzeczywistnieniem idei organizacji z jej wartościami, zasadami.

To, o czym piszę, uchwycił kilka lat temu Tomasz Wiech w serii fotografii Something Private (2007-2009), dokumentującej różne sposoby indywidualizacji przestrzeni i subtelności kształtowania żywej tkanki krakowskich biur5. Rozpoczynając swój projekt, Wiech postrzegał świat korporacji, jako coś bardzo zimnego, nieludzkiego, jako przestrzeń, w której wszystko jest jednakowe, a człowiek jest w niej mały i nic nie znaczy.

\footnotetext{
organizacji pracy. Ten językowy charakter symbolicznego kreowania nowoczesności w korporacjach jest niezwykle istotny, ale trudny do omówienia w ramach tego artykułu. Zagadnienie to opisałam i sproblematyzowałam w książce Sieci wiedzy w rozdziale Zarzadzanie jako sztuka nadawania nazw (Dudek 2018, s. 212-218).

5 Dziękuję Tomaszowi Wiechowi za rozmowę o projekcie i udostępnienie zdjęć z cyklu Something Private. Fotografia Corporation Breakfast (Something Private) została nagrodzona (trzecie miejsce) w konkursie World Press Photo 2009 w kategorii „Życie codzienne” (por. Niemczyńska 2009). Część zdjęć ukazała się w „Dużym Formacie” „Gazety Wyborczej” (23.02.2009). Wybrane fotografie można również obejrzeć na stronie https://www.lensculture.com/tomaszwiech?modal=project-4012.
} 
W miarę wykonywania kolejnych zdjęć, zaczął jednak odnajdywać na nich coraz więcej śladów wydeptanych przez ludzi, którzy zamiast zginąć w korporacyjnej dżungli budują w niej swoje „domy”, kreują swoje miejsca. Reportaż Wiecha nie jest jednak tylko prostą inwentaryzacją tych praktyk. One raczej bardzo subtelnie wyłaniają się w toku lektury jego fotograficznego eseju - drobne szczegóły, imponderabilia codziennego życia w korporacji, na które oglądający mimowolnie zwraca uwagę. Doskonale ilustrują powstawanie antropologicznych miejsc i nagromadzenie rzeczy.

Zadomawianie $\mathrm{w}$ przestrzeni biura to również umieszczanie $\mathrm{w}$ nich znaczników wspierających budowanie i wykonywanie roli organizacyjnej. Praca i komunikacja organizacyjna są formą performansu kulturowego ${ }^{6}$. Biuro jest również „sceną”, na której występują pracownicy ${ }^{7}$ Erving Goffman pisał, że zwykle oczekuje się pewnego stopnia zgodności między dekoracją, powierzchownością, którą definiuje jako zespół bodźców pouczających nas o społecznych statusach jednostki oraz sposobem bycia - przesłankach pozwalających określić, jaką rolę w interakcji jednostka spodziewa się odgrywać w danej sytuacji ${ }^{8}$. Zadomowienie wiąże się z zaaranżowaniem otoczenia, wypełnionego odpowiednimi przedmiotami, które może stać się częścią organizacyjnego performansu.

\section{Prywatność i praktyki oporu w biurach terytorialnych}

Oznaczanie przestrzeni i przekształcanie jej jest także metodą obrony symbolicznej przed opresyjnością organizacji lub tego, co wiąże się z wykonywanymi zadaniami przeobrażaniem przestrzeni, które daje poczucie kontroli i sprawczości. To tworzenie bezpiecznej enklawy. Ostatni przykład: Katarzyna z działu administracji dużej spółki z branży energetycznej oprowadza mnie po biurze, chciała wyjaśnić wszystko jeszcze przy recepcji, bo jak wejdziemy, to już trzeba zachować ciszę. „No to jest nasz open space" - wyszeptała, gdy znalazłyśmy w przestrzeni wewnętrznej biura. Stałyśmy w przestrzeni ciągu komunikacyjnego. Spojrzałam w prawo: widać było jedynie dość wysoką pierzeję z szarych paneli. Spojrzałam w lewo: to samo. Po środku, na wysokości wzroku przypięto białą kartkę z napisem „prosimy o ciszę”. Za pierzeją paneli schowane były biurka poodgradzane dodatkowo wysokimi szafami na dokumenty. Jak wyjaśniała Katarzyna, w tych szafach na ogół nic nie przechowywano, dlatego działały jak pudła rezonansowe i zamiast tłumić, potęgowały roznoszenie się dźwięków. Jak się później przekonałam, atmosfera była dość napięta a przestrzeń stała się narzędziem walki symbolicznej.

Tworzenie zakamarków, wydzielonych szafami, chowanie się w zakamarkach, przenoszenie się z pracą do przestrzeni pustych ${ }^{9}$, nieuczęszczanych (takich jak serwerownie,

\footnotetext{
6 Pacanowsky, Trujillo 1996.

7 Pacanowsky, Trujillo 1996, s. 291.

8 Goffman 2000, s. 54-55.

9 O przestrzeniach pustych pisali szerzej Kostera, Kociatkiewicz 1997.
} 
magazynki, klatki ewakuacyjne) to sposoby na ucieczkę przed byciem na widoku, ciągle wśród ludzi, zawsze słyszanym. Kategoria prywatności stała się w XX wieku niezwykle pożądaną $\mathrm{i}$ istotną wartością ${ }^{10}$. Włodzimierz Filipek nazywa ją nieuchwytną realnością, ponieważ między tym, co prywatne, a tym, co publiczne rozciąga się niewidzialna kurtyna. Chociaż nie pozostawia ona świadectw bezpośrednich i unika spektakularnych manifestacji, to jednak niewątpliwie ma ona materialną infrastrukturę. Tworzy na swoje potrzeby przestrzenne konstrukcje, w których się realizuje. Powstanie owego mikrokosmosu prywatności Filipek łączy z wielkimi zmianami społecznymi związanymi z reformacją, rozwojem urbanizacji i kapitalizmu, dokonującymi się w duchu liberalizmu ${ }^{11}$.

W badaniach nad realizowaniem prywatności w organizacjach bierze się pod uwagę zarówno aspekt psychologiczny (definiowany jako możliwość kontroli intensywności interakcji ze współpracownikami, dostępu innych do informacji, które się otrzymuje i wysyła), jak i bada się stopień realizowania zasad prywatności przez środowisko fizyczne ${ }^{12}$. Przyjmuje się, że owa „architektoniczna prywatność” uzależniona jest od stopnia wizualnej i akustycznej izolacji, którą zapewnia infrastruktura biura. Obie formy realizowania się prywatności wpływają na poczucie satysfakcji z wykonywanej pracy i są od siebie zależne. Zadomawianie przestrzeni biura jest więc także tworzeniem enklaw prywatności, oznaczaniem swojej przestrzeni poprzez jej wizualne wydzielenie.

\section{Nowe strategie korporacyjne: biura nieterytorialne}

Opisane wyżej taktyki zadomawiania realizowane są w biurach tradycyjnych, w których określonym osobom i grupom osób przydzielone są konkretne przestrzenie. Taki typ organizacji biur stopniowo jest zastępowany przez modele, w których przestrzeń jest w coraz mniejszym stopniu „czyjaś”. I dlatego ostatnie lata to bardzo ciekawy okres dla antropologa badającego tworzenie przestrzeni organizacyjnych. Zmiany, które można zaobserwować, dotyczą kilku obszarów organizacji pracy i powiązane są ze zmianami aranżacji biur.

$\mathrm{Na}$ tempo zmian duży wpływ ma bardzo dynamiczny rozwój rynku powierzchni

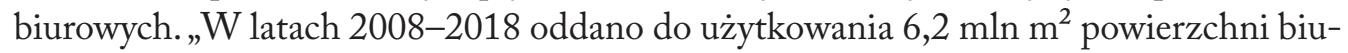
rowej w Polsce. Obecnie jej zasoby osiągnęły $9,9 \mathrm{mln} \mathrm{m}^{2}$, co oznacza, że przez ostatnią dekadę wielkość powierzchni biurowej w Polsce wzrosła prawie trzykrotnie"13. Ten wzrost dotyczy oczywiście przede wszystkim większych miast, takich jak Warszawa, Kraków, Trójmiasto, Wrocław czy Łódź. Na tych milionach metrów kwadratowych nowej powierzchni biurowej zaczęto eksperymentować ze sposobami aranżowania

\footnotetext{
${ }^{10}$ Filipek 1998, s. 59; Por. Rybczyński 2003, s. 81.

${ }^{11}$ Filipek 1998, s. 60-61.

${ }^{12}$ Sundstrom, Burt, Kamp 1980, s. 101-102.

${ }_{13}$ Workplace Strategy... 2018, s. 21.
} 
przestrzeni (jak m.in. zadaniowa organizacja biura ${ }^{14}$, współdzielenie biurek ${ }^{15}$ ), nowymi technologiami (np. systemy do rezerwacji przestrzeni) i meblami (przenośne budki telefoniczne i salki konferencyjne, meble wygłuszające wykonane $\mathrm{z}$ materiałów akustycznych). W tym samym czasie równolegle i stopniowo dokonywała się w organizacjach transformacja cyfrowa - wymieniano komputery PC na laptopy, telefony stacjonarne na telefony komórkowe, w wielu wprowadzono internet mobilny oraz zdalny dostęp do serwerów oraz dokumentów „w chmurze”. W wyniku tych zmian część pracujących stała się bardziej mobilna i mogła pracować już nie tylko przy własnym biurku, lecz także $\mathrm{w}$ innych miejscach $\mathrm{w}$ biurach i poza nimi. W wielu organizacjach wprowadzono częściową pracę zdalną (pracę w domu jeden dzień w tygodniu lub częściej). Jednocześnie popularne stały się tzw. zwinne metody zarządzania i organizowania pracy. Obok tradycyjnych podziałów departamentowych, w ramach których poszczególne działy zajmowały określone przestrzenie i tam pracowały, zaczęto wprowadzać miejsca pracy dla zespołów składających się z osób zatrudnionych w różnych działach lub wręcz zatrudnianych przez firmy zewnętrzne (tworzące struktury procesowe, produktowe i projektowe). Małe i średnie przedsiębiorstwa a nawet przez korporacje zaczęły wynajmować przestrzenie „coworkingowe” (ang. coworking space), które początkowo kierowały swoją ofertę do niezależnych specjalistów. W efekcie tych wszystkich zmian przestrzenie w biurach zaczęły stawać się w coraz mniejszym stopniu przynależne konkretnym osobom.

I ma to jeszcze jedną konsekwencję dla reguł korzystania z przestrzeni. Organizacje starają się dzięki przestrzeniom stworzyć wrażenie doskonałości i nowoczesności, co ma swoje odzwierciedlenie nie tylko w samym projekcie biura, lecz także w przyjmowanych procedurach działania. Mam tu na myśli przede wszystkim zwyczaj pozostawiania na koniec dnia pracy czystych, niczym niezastawionych biurek, sygnalizujący, że wszystkie

${ }^{14}$ Ang. activity-based workplace. Przestrzeń biura podzielona jest na obszary, w których wykonywane są różne czynności, np. przestrzeń do pracy w skupieniu, przestrzeń do pracy zespołowej, miejsca, w których pracownicy mogą coś krótko omówić, budka do wykonywania rozmów telefonicznych, itd. Od bardziej tradycyjnych sposobów organizacji przestrzeni - takich jak układ gabinetowy (osobne, zamykane pokoje, usytuowane wzdłuż korytarzy) czy biuro na planie otwartym (ang. open space, gdzie biurka znajdują się w dużej otwartej przestrzeni, spotkania prowadzone są w salach konferencyjnych) - zadaniową organizację biura odróżnia większa różnorodność przestrzeni i jej sposób wykorzystywania, wymagający od pracowników przemieszczania się pomiędzy poszczególnymi obszarami, zaprojektowanymi w taki sposób, by wykonywać tam określony rodzaj czynności.

${ }^{15}$ Ang. hot-desking - sposób organizacji pracy w biurze, polegający na tym, że nikt nie ma własnego biurka, lecz zajmuje to, które jest aktualnie wolne. Pomysł na takie zarządzanie przestrzenią wynikał z obserwacji, że biurka są na ogół wykorzystywane tylko w 40\%, ponieważ ich użytkownicy są albo na spotkaniach w biurze, albo poza nim. Wprowadzono więc współdzielenie biurek, by zwiększyć efektywność ich wykorzystania. Jednocześnie wprowadza się redukcję liczby biurek w stosunku do liczby pracowników (np. przyjmuje się proporcję 8 na 10). Wiele firm, żeby uniknąć chaosu, przydziela poszczególnym grupom przestrzenie, w ramach których współdzielą oni biurka. Każdy zespół ma swoją „bazę”, aby mimo częstych zmian biurek pracownicy mogli się łatwo odnaleźć. 
zadania zostały wykonane. Ale wiąże się też z koniecznością współdzielenia przestrzeni, która uporządkowana, pozbawiona znaczników osobistych ma być w każdej chwili dostępna do pracy dla różnych osób. Zasada ta prowadzi do depersonalizacji przestrzeni i czyni ją nijaką.

Zadomawianie przestrzeni organizowanych zgodnie $\mathrm{z}$ nowymi koncepcjami jest grą między menedżerami i podwładnymi. Ci drudzy dążą do odzyskania utraconych terytoriów biurowych, próbują pozostawiać swoje rzeczy w miejscach do tego nieprzeznaczonych, ci pierwsi odpowiadają organizowaniem zespołów pilnujących porządku i wdrażają procedury zbierania pozostawionych rzeczy i oddawania ich do „biura rzeczy znalezionych".

\section{Dizajn zadomawiający. Przechwytywanie taktyk i strategii}

Producenci mebli nie tylko śledzą zmiany w technologiach, sposobach zarządzania, lecz także prowadzą badania, by rozpoznać potrzeby użytkowników. Polscy producenci mebli naśladują w tym względzie strategie międzynarodowych przedsiębiorstw takich jak Steelcase czy Kinnarps. Przechwytują zarówno strategie korporacyjne i tworzą rozwiązania dopasowane do nowych mobilnych stylów pracy, jak i taktyki pracowników dążących do zadomowienia przestrzeni. Ich działania kształtują wszystkie przestrzenie biurowe, ale przede wszystkim ich udział w procesach zadomawiania przestrzeni ujawnia się w przestrzeniach biur nieterytorialnych.

Po pierwsze, meble biurowe coraz bardziej przypominają meble domowe: miękkie wykończenia, obłe kształty, nowe palety barw, ciepłe i stonowane. W katalogach i w materiałach promocyjnych, zamieszczanych na stronach internetowych czy w mediach społecznościowych, pojawiają się zdjęcia aranżacji przypominające domowe wnętrza, np. narożna kanapa z poduszkami, rzucony pled, przed nią niska ława, na której stoją szklanki, w tle regał, obrazy i kilka doniczek z dużymi roślinami, całość utrzymana w tonacji szaro-beżowej z pastelowymi akcentami ${ }^{16}$. „Soft seat doskonale wpisuje się w trend hospitality, który jest uzupełnieniem home office design. Dąży do zapewnienia najwyższego komfortu i pozwala pracownikom na chwilę wytchnienia" - przeczytać można w magazynie firmy Grupa Nowy Sty ${ }^{17}$. Liczne przykłady nawiązywania do aranżacji ,jak w domu" znaleźć można w warstwie zarówno wizualnej, jak i dyskursywnej.

$\mathrm{O}$ ile sofy, kanapy czy fotele w tradycyjnych biurach terytorialnych znajdowały się w przestrzeni recepcji, gdzie mogli na nich spocząc klienci oczekujący na spotkanie, lub w gabinecie prezesa, o tyle dziś wykorzystywane są w przestrzeniach pracy. Za ich pomocą tworzone są miejsca do spotkań nieplanowanych, wydzielone panelami akustycznymi czy roślinami, by odpowiedzieć na potrzebę wynikającą z coraz bardziej

\footnotetext{
${ }^{16}$ Przykład zaczerpnięty z dwujęzycznego katalogu Trends... 2018 prezentującego biurowe trendy.

${ }^{17}$ LinkUP: Odpocznij i nabierz energii do pracy. "Upstream” nr 7, http://www.nowystyl.pl/pub/up_stream/07.pdf, s. 21.
} 
dynamicznego stylu działania organizacji i większej liczby krótkich spotkań i konsultacji między pracownikami, jak również ze względu na chęć przebywania w przyjaznych, niekorporacyjnych wnętrzach. Tworzone są nie tylko komfortowe zakątki. Miękkie meble trafiają też do sal konferencyjnych, szczególnie tych mniejszych, przeznaczonych dla kilku osób, w których aranżowane są miejsca do rozmów telefonicznych (wygodny fotel, lampa stojąca i stolik kawowy), miejsca do spotkań nieformalnych czy rozmów rekrutacyjnych, jak również do sal służących do zespołowej pracy kreatywnej. Nowe typy mebli wykorzystywane są także w otwartych przestrzeniach projektowanych na wzór kawiarni, aby pracownicy mogli realizować zadania $\mathrm{w}$ innych przestrzeniach niż gabinety, open space i salki konferencyjne. Możliwość personalizowania stanowiska pracy zostaje przekształcona w możliwości dokonywania wyboru przestrzeni, w której się w danym momencie pracuje, zaaranżowanej ,jak w domu”.

Po drugie, producenci mebli oferują produkty, dzięki którym można tworzyć aranżacje poddające się łatwo przekształcaniu bez konieczności wykonywania robót budowlanych. Produkty te tworzą możliwość wydzielania i oddzielania zarówno wizualnego, jak i akustycznego (współgrają zatem z pracowniczymi taktykami), ale jednocześnie nie tworzą sztywnych konstrukcji (współgrają zatem ze strategiami korporacyjnymi i dążeniem do tworzenia elastycznych przestrzeni, łatwo poddających się reorganizacji). W ofercie producentów mebli znaleźć można nie tylko miękkie kanapy i fotele, lecz także elementy ułatwiające organizację pracy (tzw. organizery), w których można przenosić i trzymać różne przedmioty, szafki na rzeczy osobiste, kotary i zasłony akustyczne oraz panele, pomagające wydzielić przestrzeń. Z myślą o zapewnianiu komfortu akustycznego opracowywane są poszczególne produkty firm meblarskich. Istnieją też wytwórcy, których celem jest wsparcie projektowania zrównoważonych środowisk akustycznych, oferujący wyłącznie meble biurowe posiadające właściwości absorpcyjne i izolujące, a dzięki temu pochłaniające dźwięki (eliminujące odbicia fal dźwiękowych i zmniejszające pogłos).

Po trzecie, przechwytywanie strategii i taktyk ma również wymiar niematerialny związany z praktykami projektowania wykorzystywanymi i promowanymi przez producentów mebli biurowych. Zachęcają oni swoich klientów - podobnie zresztą jak pracownie architektoniczne czy agencje nieruchomości - do zapraszania pracowników do współtworzenia przestrzeni. Organizowane są warsztaty, wykorzystujące metodologie design thinking i podobne, by włączyć pracowników w proces projektowania miejsca pracy. Pracownicy wspólnie z osobami prowadzącymi warsztaty wybierają typy aranżacji funkcjonalnych, które będą dobrze współgrały z ich charakterem pracy. Mają także, w ograniczonym zakresie, wpływ na decyzje dotyczące designu, by dobrze oddawał kulturę i charakter organizacji. W ten sposób tworzenie miejsca zostaje zinstytucjonalizowane i włączone w korporacyjny porządek. Tego typu działania są częścią szerszej strategii sprzedaży, meble i inne produkty są bowiem sprzedawane wraz z dodatkowymi 
usługami mającymi zwiększyć wartość dodaną dla klienta ${ }^{18}$, takimi jak utylizacja starych mebli, pomoc w projektowaniu nowej przestrzeni, audyty akustyczne, usługi serwisowania mebli a nawet sprzedaży mebli jako usługi (furniture as service).

\section{Zakończenie. Nowe formy zadomowienia?}

Przestrzeń biura dla wkraczającej w nią po raz pierwszy osoby jest czymś obcym i dopiero kiedy jest odczuwana jako dobrze znana, zaczyna konotować rozległe pola semantyczne o charakterze estetycznym i emocjonalnym, wysyca się prywatnymi biografiami, minionymi praktykami, staje się miejscem. Wypełnianie przedmiotami i oznaczanie przestrzeni jest możliwe w tradycyjnym biurze terytorialnym, ale trudno tę taktykę stosować w przestrzeniach, w których nie ma przypisanych miejsc. Można więc sądzić, że jedna z nowoczesnych strategii widocznych we współczesnych biurach wiedzie do depersonalizacji i oddomowienia. Producenci mebli potrafią wykorzystać zarówno odgórne, korporacyjne praktyki, jak i działania oddolne i wmontować je w swoje strategie. Taktyki związane $\mathrm{z}$ zadomawianiem przestrzeni biur, będące odpowiedzią na zmiany na rynku nieruchomości i nowe sposoby zarządzania, kształtują się jednak cały czas i warto im poświęcić więcej uwagi badawczej.

\section{Bibliografia}

LinkUP: Odpocznij i nabierz energii do pracy, "Upstream" no.7, http://www.nowystyl.p1/pub/up_ stream/07.pdf, 31.01.2019.

Bowman C., Ambrosini V.2010, How value is created, captured and destroyed, "European Business Review", Vol. 22 No. 5, s. 479-495.

de Certeau M. 2008, Wynaleźć codzienność. Sztuka dziatania, Wydawnictwo Uniwersytetu Jagiellońskiego, Kraków.

Dudek K. 2018, Sieci wiedzy. Teoria zarzadzania między naukq a praktyka, Universitas, Kraków.

Filipek W. 1998, Prywatność: nieuchwytna realność [w:] Zeidler-Janiszewska A. (red.), Formy estetyzacji przestrzeni publicznej, Instytut Kultury, Warszawa.

Goffman E. 2000, Cztowiek w teatrze życia codziennego, Wydawnictwo KR, Warszawa.

Kostera M., Kociatkiewicz J. 1997, Antropologia pustych przestrzeni [w:] Zeidler-Janiszewska A. (red.), Pisanie miasta - czytanie miasta, Humaniora, Poznań, s. 83-81.

Niemczyńska M. 2009, Zimny korpus korporacji, „Gazeta Wyborcza. Duży Format”, 23.02, s. 8-9. Pacanowsky M. E., Trujillo N. O. 1996, Komunikacja organizacyjna jako forma "wykonania" kulturowego [w:] Kapciak A., Korporowicz L., Tyszka A. (red.), Komunikacja międzykulturowa. Zderzenie i spotkania, Instytut Kultury, Warszawa, s. 287-316.

${ }^{18} \mathrm{~W}$ nurcie badań nad tworzeniem wartości podkreśla się, że wartość to nie tylko wartość ekonomiczna, lecz także wartość użytkowa (Bowman, Ambrosini, 2010). 
Rybczyński W. 2003, Najpiękniejszy dom na świecie, Wydawnictwo Literackie, Kraków.

Sundstrom E., Burt R.E., Kamp D.1980, Privacy at Work:Architectural Correlates of Job Satisfaction and Job Performance, „The Academy of Management Journal”, nr. 23/1, s. 101-117.

Trends..., 2018, Trends, Technology, Lifestyle, Noti, Balma, Tarnowo Podgórne.

Tuan Y. F. 1987, Przestrzeń i miejsce, Państwowy Instytut Wydawniczy, Warszawa.

Workplace Strategy... 2018, Workplace Strategy - zaprojektuj doświadczenie w pracy i wyprzedź jutro, BNP Paribas Real Estate, Warszawa. 